\title{
Food and Grain Consumption Per Capita in the Qinghai-Tibet Plateau and Implications for Conservation
}

\author{
Lijing Wang ${ }^{1,2}$, Yi Xiao ${ }^{1}$ and Zhiyun Ouyang ${ }^{1, *(\mathbb{D}}$ \\ 1 State Key Laboratory of Urban and Regional Ecology, Research Center for Eco-Environmental Sciences, \\ Chinese Academy of Sciences, Beijing 100085, China; wanglijingcas@163.com (L.W.); xiaoyi@rcees.ac.cn (Y.X.) \\ 2 University of Chinese Academy of Sciences, Beijing 100049, China \\ * Correspondence: zyouyang@rcees.ac.cn; Tel.: +86-010-6284-9191
}

Citation: Wang, L.; Xiao, Y.; Ouyang, Z. Food and Grain Consumption Per Capita in the Qinghai-Tibet Plateau and Implications for Conservation.

Nutrients 2021, 13, 3742.

https://doi.org/10.3390/nu13113742

Academic Editor: Maria Kapsokefalou

Received: 13 October 2021

Accepted: 21 October 2021

Published: 23 October 202

Publisher's Note: MDPI stays neutral with regard to jurisdictional claims in published maps and institutional affiliations.

Copyright: () 2021 by the authors. Licensee MDPI, Basel, Switzerland. This article is an open access article distributed under the terms and conditions of the Creative Commons Attribution (CC BY) license (https:// creativecommons.org/licenses/by/ $4.0 /)$.
Abstract: Background: Grain security is crucial for social stability and ecosystem conservation regionally and globally, and it is particularly concerned widely in the Qinghai-Tibet Plateau (QTP) due to its high altitude and harsh climate for agriculture. Method: In this paper, we calculated and analyzed per capita food and grain consumption, including direct grain consumption, grain for fodder, industry consumption, seeds consumption, and wastage consumption and its changes in the QTP during 1995-2019. Results: The results showed that (1) in 2019, the average food consumption per capita was $333.35 \mathrm{~kg}$, was stable since 1995. The dietary structure of residents was composed of direct grain consumption $(44.15 \%)$, meat $(10.72 \%)$, and milk (6.94\%). The consumption of meat and milk was higher than the national average. (2) The average daily intake of energy and protein, animal protein, and the ratio of high-quality protein and fat energy were $2156.21 \mathrm{kcal} \cdot \mathrm{d}^{-1}, 73.53 \mathrm{~g} \cdot \mathrm{d}^{-1}, 23.06 \mathrm{~g} \cdot \mathrm{d}^{-1}$, $38.32 \%$, and $27.77 \%$ in 2019 . Their changes were $-342.98 \mathrm{kcal} \cdot \mathrm{d}^{-1},-8.91 \mathrm{~g} \cdot \mathrm{d}^{-1}, 11.16 \mathrm{~g} \cdot \mathrm{d}^{-1}, 18.37 \%$, and $11.08 \%$, respectively. (3) The corresponding grain consumption per capita was $284.90 \mathrm{~kg} \cdot \mathrm{a}^{-1}$ in $1995,262.19 \mathrm{~kg} \cdot \mathrm{a}^{-1}$ in 2010, and then remained stable until 2019. Conclusion: The study suggested that food consumption per capital was guaranteed at the well-off level since 2010, and food and dietary structure of residents were corresponding to physical geographic and climatic environment in the QTP. The conflict between food security and the ecosystem conservation can be managed without scarifying nature as the total grain consumption was stable since 2010, and the yield per unit area and total grain yield were both increasing since 2003 for agricultural condition improved in the QTP.

Keywords: nutrient; per capita grain consumption; grain security; Qinghai-Tibet Plateau

\section{Introduction}

Grain security is very important to residents' wellbeing, social stability, and regional economic development [1-3]. Grain consumption per capita is the basic index to evaluate grain security from the demand side, which is of great significance for research on regional grain security for their abundant nutrients $[4,5]$. At present, grain consumption per capita has been studied from five aspects: direct grain consumption, grain for fodder, industry consumption, seeds consumption, and wastage consumption [6,7]. The dietary habits of residents in various regions are different, although the demand in nutrients for humans is almost the same, so we can calculate the corresponding grain consumption. Tang suggested that the maximum per capita grain demand in China under the dietary balance mode was $386.6 \mathrm{~kg} \cdot \mathrm{a}^{-1}$ [8]. While, Xie believed it was $384 \mathrm{~kg} \cdot \mathrm{a}^{-1}$ based on nutrients' demand in the new era [9]. The per capita grain demand standard in China was $400 \mathrm{~kg}$ as the nutrient intake standard of the well-off level [10]. The standard has been an important reference in policy making for national and regional grain production and security in China $[1,11-16]$.

Due to its unique geographical conditions, ecosystems, population composition, and dietary habits, the grain security in the QTP has attracted extensive attention [17-19]. The dietary structure of residents in the QTP is different from the nationwide average of China. 
The QTP is the highest-altitude region in the world. There are few land resources suitable for cultivated land, but it is more suitable for forage. The dominant ecosystem type in the QTP is the grassland ecosystem [20], which is essential for development of animal husbandry. Correspondingly, the residents in the QTP had higher consumption of beef, mutton, and milk, and lower consumption of vegetables and aquatic products than the residents in other regions. The main energy, protein, and fat obtained by Tibetan in Qinghai Province come from animals. Mongolia and Kazak also have a similar situation [10].

There was a long debate regarding whether the population in Tibet was overloaded or not, it was a challenge for ecosystem protection and restoration programs. Hao and others discovered that the population of the Tibet was not overloaded [21]. The conclusion was opposite to the previous research results $[22,23]$. Therefore, it is necessary to analyze grain consumption that is suitable for the QTP to evaluate the grain security in this region.

We studied the per capita food and grain consumption through direct grain consumption, grain for fodder, industry consumption, seeds consumption, and wastage consumption from the perspective of nutritional demand in the QTP from 1995 to 2019. The purpose of this study was to explore how food and dietary structure of residents correspond to physical geographic and climatic environment, and test whether the conflict between food security and the ecosystem conservation can be managed.

\section{Material and Methods}

\subsection{Study Area}

The QTP is a unique geological-geographical-ecological unit [24], located in the interior of Asia, and known as the "Roof of the World", with an average altitude of more than $4000 \mathrm{~m}$. Its total area is about 2.56 million $\mathrm{km}^{2}$ [25]. Qinghai and Tibet are located in the core of the QTP, with a total population of 9.58 million in 2018. There were 5.76 million Tibetans, accounting for $60.10 \%$ of the total population. Taking the two provinces as the representatives of the QTP, this study analyzed the per capita food and grain consumption in this region.

\subsection{Method}

\subsubsection{Per Capita Grain Consumption}

The food in this study include direct grain consumption, edible oil (vegetable oil and animal oil), meat (pork, beef, and mutton), poultry, aquatic products, eggs, dairy, vegetables, fruits, sugar and alcohol, the grains include cereals, beans, and tubers. Additionally, the grain-consuming animal products include animal oil, meat, poultry, aquatic products, eggs, and dairy, so they can be transformed into grain for fodder, the same with alcohol.

In this study, according to the production sources of food consumed by residents, the grain consumption was divided into five types: direct grain consumption, grain for fodder, industry consumption, seed consumption, and wastage consumption (Figure S1). The grain for fodder, industry consumption, seed consumption, and wastage consumption are all indirect grain consumption. The sum of the five types of grain was the per capita grain consumption. The per capita grain consumption was calculated using the following formula [8]:

$$
G=\sum_{i=1}^{n} g_{i}
$$

where $G$ was the per capita grain consumption and $g_{i}$ was the $i$ type grain consumption. In this paper, the weighted average of Qinghai and Tibet provinces represents the per capita grain consumption in the QTP.

\subsubsection{Direct Grain Consumption}

The direct grain consumption was calculated using the following formula [8]:

$$
D=\sum_{i=1}^{n} P_{i} \cdot\left(B D_{i}+O D_{i}\right)
$$


where $D$ was per capita direct grain consumption, $P_{i}$ was the population proportion of the $i$ region, $B D_{i}$ was the per capita direct grain consumption purchase or consumption at home in the $i$ region, and $O D_{i}$ was the per capita direct grain consumption out of home in the $i$ region. In this study, there were two regions, namely, urban and rural.

\subsubsection{Grain for Fodder}

The grain for fodder was calculated using the following formula [8]:

$$
F=\sum_{i=1}^{n} \sum_{j=1}^{n}\left(\frac{B A_{i j}+O A_{i j}}{1-L_{j}} \cdot C_{j}\right)
$$

where $F$ was per capita grain for fodder, $B A_{i j}$ was the consumption of the $j$ animal product in the $i$ region at home, $O A_{i j}$ was the consumption of the $j$ animal product in the $i$ region out of home, $L_{j}$ was the loss rate of the $i$ animal product, and $C_{j}$ was the grain consumption coefficient of the $j$ animal product. There were seven animal products in this study, namely, pork, beef, mutton, poultry, eggs, milk, and aquatic products.

\subsubsection{Industry Consumption}

The industry consumption was calculated using the following formula [8]:

$$
I N=\sum_{i=1}^{n} \sum_{j=1}^{n}\left[\left(B W_{i j}+O W_{i j}\right) \cdot C_{j}\right]
$$

where $I N$ was industry consumption, $B W_{i j}$ was the per capita consumption of the $j$ industrial product in the $i$ region at home, $O W_{i j}$ was the per capita consumption of the $j$ industrial product in the $i$ region out of home. $C_{j}$ was the grain consumption coefficient of the $j$ industrial product. There were two industrial products in this study, namely, Chinese Baijiu and beer.

\subsubsection{Seeds Consumption}

The seeds consumption was calculated using the following formula [8]:

$$
S=G_{p} \cdot S R
$$

where $S$ was seed consumption, $G_{p}$ was the per capita grain yield, and $S R$ was the proportion of seed grain.

\subsubsection{Wastage Consumption}

The wastage consumption was calculated using the following formula [8]:

$$
W A=G_{p} \cdot W R
$$

where $W A$ was the wastage consumption and $W R$ was the grain loss rate.

\subsection{Data Sources}

\subsubsection{Food Consumption at Home}

The annual average number of commodities purchased by urban households, the average consumption of main food by rural households, and the urban and rural population were derived from the Qinghai Statistical Yearbook [26] and the Tibet Statistical Yearbook [27].

\subsubsection{Food Consumption out of Home}

The proportion of residents dining out of home comes from the survey data of the China chronic disease surveillance questionnaire [28], the food composition of residents dining out comes from the data of the China Health and Nutrition Survey [29], the expendi- 
ture of urban residents dining out of home comes from the Qinghai Statistical Yearbook [26] and the Tibet Statistical Yearbook [27], and the expenditure of rural residents on dining out of home comes from the Yearbook of China's rural household survey [30]. The data for other years were interpolated by the consumption ratio of urban and rural residents [31].

\subsubsection{Direct Grain Consumption}

Direct grain consumption was calculated when we collected the data in Sections 2.3.1 and 2.3.2.

\subsubsection{Grain for Fodder}

Based on the research on grain for fodder by Han [32] and others, combined with the loss rate and grain consumption coefficient of animal products $[9,33,34]$ at a similar time, the loss rate and grain consumption coefficient of animal products were formulated.

\subsubsection{Industry Consumption}

Industry consumption included the grain used in Chinese Baijiu and beer. The data were from the Qinghai Statistical Yearbook [26] and the Tibet Statistical Yearbook [27]. The grain consumption coefficient was obtained by referring to the research results of Tang [8] and Shen [35].

\subsubsection{Seeds Consumption}

The sowing area of grain and the average sowing data per unit area were from the China Statistical Yearbook [36] and the national compilation of cost-benefit data of agricultural products [37]. The national proportion of seed consumption was taken as the standard of the QTP.

\subsubsection{Wastage Consumption}

The grain loss rate was estimated as $4 \%$ in this paper, according to the actual situation in the process of grain transportation, storage, and management [38].

\subsubsection{Nutrient Content of Foods}

The nutrient content of foods comes from the China Food Composition Tables Standard Edition [39,40]. The proportion of food composition referred to the research of China's Medium and Long Term Food Development Strategy [10] and Gao [19] and Liu [17] (Table S1).

\subsubsection{Well-Off Nutritional Level}

According to the well-off nutritional level proposed in China's Medium and Long Term Food Development Strategy [10] and Chinese Dietary Reference Intakes proposed in the dietary nutrient reference intake of Chinese residents [41], the well-off nutritional level in this study was proposed: the daily per capita energy intake is $2100 \mathrm{kcal} \cdot \mathrm{d}^{-1}$ and the protein is $70 \mathrm{~g} \cdot \mathrm{d}^{-1}$, of which the high-quality protein accounts for more than $30 \%$ and animal protein accounts for more than $20 \%$, the ratio of energy from fat is $20-25 \%$.

\section{Results}

We calculated and analyzed per capita food and grain consumption, and nutrient intakes in the QTP during 1995-2019. The grain consumption included direct grain consumption, grain for fodder, industry consumption, seeds consumption, and wastage consumption.

\subsection{Food Consumption Per Capita and Nutrient Intakes}

The total per capita food consumption in the QTP was generally stable, but the food structure was greatly changed from 1995 to 2019 (Figure 1). The total food consumption in the QTP was $333.35 \mathrm{~kg}$ in 2019. Its multi-year average was $333.77 \mathrm{~kg}$, and the anomalous 
percentage of each year was less than $8 \%$ (except for 1996). Among all types of food, the consumption of direct grain consumption declined from 221.01 to $147.17 \mathrm{~kg}$. The consumption of meat, such as pork, poultry, beef and mutton, was $9.99,3.83$, and $21.90 \mathrm{~kg}$ in 2019 , respectively. The consumption of pork only increased by $18.53 \%$, but the consumption of beef and mutton increased by $123.42 \%$. The proportion of beef and mutton had increased, and the proportion of pork had decreased year by year. Milk consumption was $23.14 \mathrm{~kg}$ in 2019 and increased by $77.05 \%$. Edible oil, poultry, aquatic products, eggs, vegetables, fruits, sugars, and alcohol also increased to some extent.
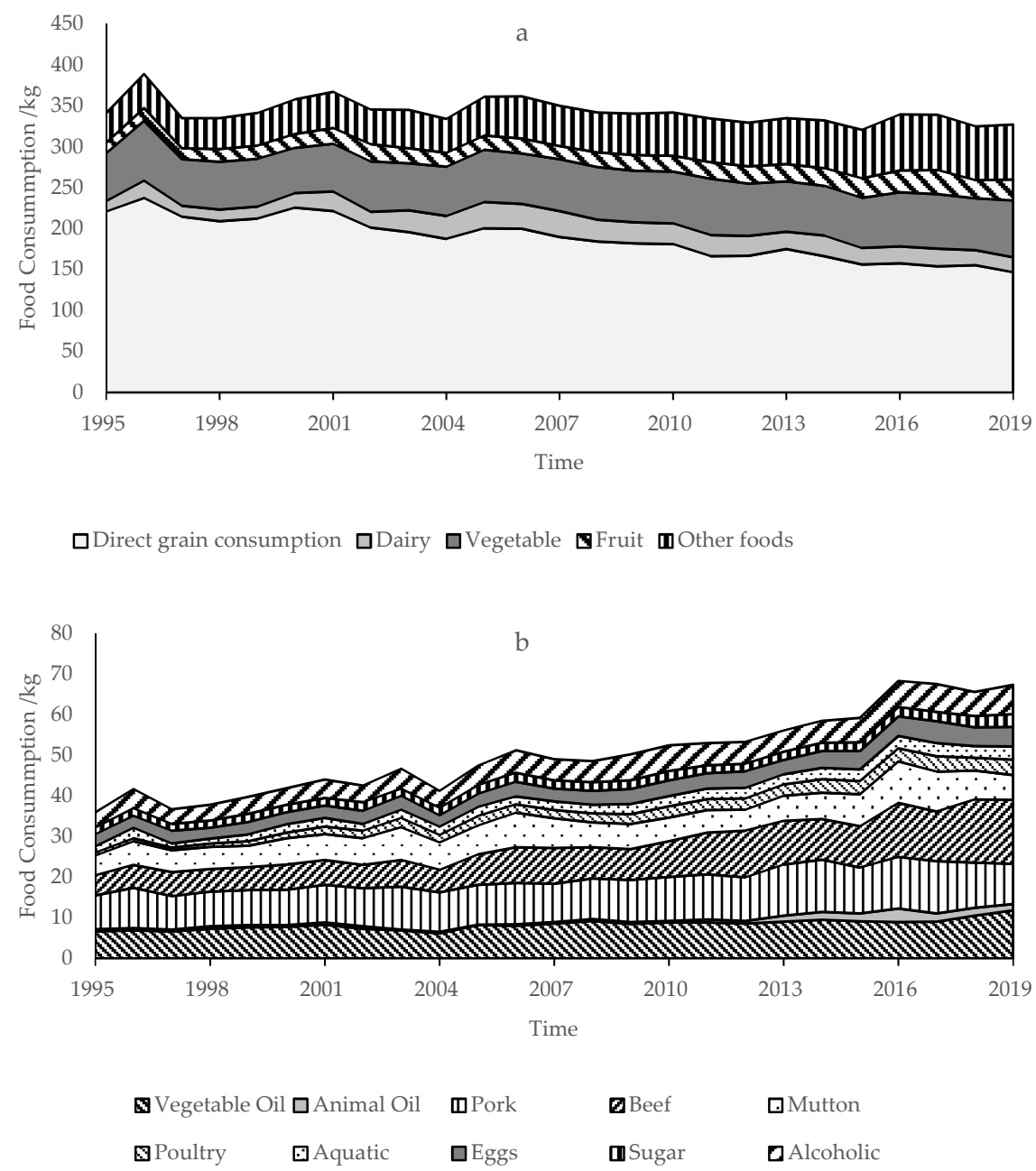

Figure 1. The structure of per capita food consumption in the QTP from 1995 to 2019 (a,b). The other food in a was displayed in $b$ to show them clearly. The foods in (b) were far less than direct grain consumption, dairy, vegetable and fruit, so they were not clear in (a).

The per capita nutrient intake and composition in the QTP was intensively changed from 1995 to 2019. The energy intake decreased from 2499.19 to $2156.21 \mathrm{kcal} \cdot \mathrm{d}^{-1}$ (Figure 2), in which the ratio of energy from carbohydrates decreased from $70.11 \%$ to $58.59 \%$, in contrast, the ratio of energy from fat increased from $16.69 \%$ to $27.77 \%$, and the ratio of energy from protein basically remained at about $13.40 \%$ (Figure 3 ). Protein intake was $73.53 \mathrm{~g} \cdot \mathrm{d}^{-1}$, and decreased by $8.91 \mathrm{~g} \cdot \mathrm{d}^{-1}$, but the ratio of animal protein and the highquality protein increased from $17.44 \%$ and $19.95 \%$ to $31.36 \%$ and $38.32 \%$, respectively (Figure 4). Fat intake was $66.53 \mathrm{~g} \cdot \mathrm{d}^{-1}$ and increased by $20.18 \mathrm{~g} \cdot \mathrm{d}^{-1}$. 


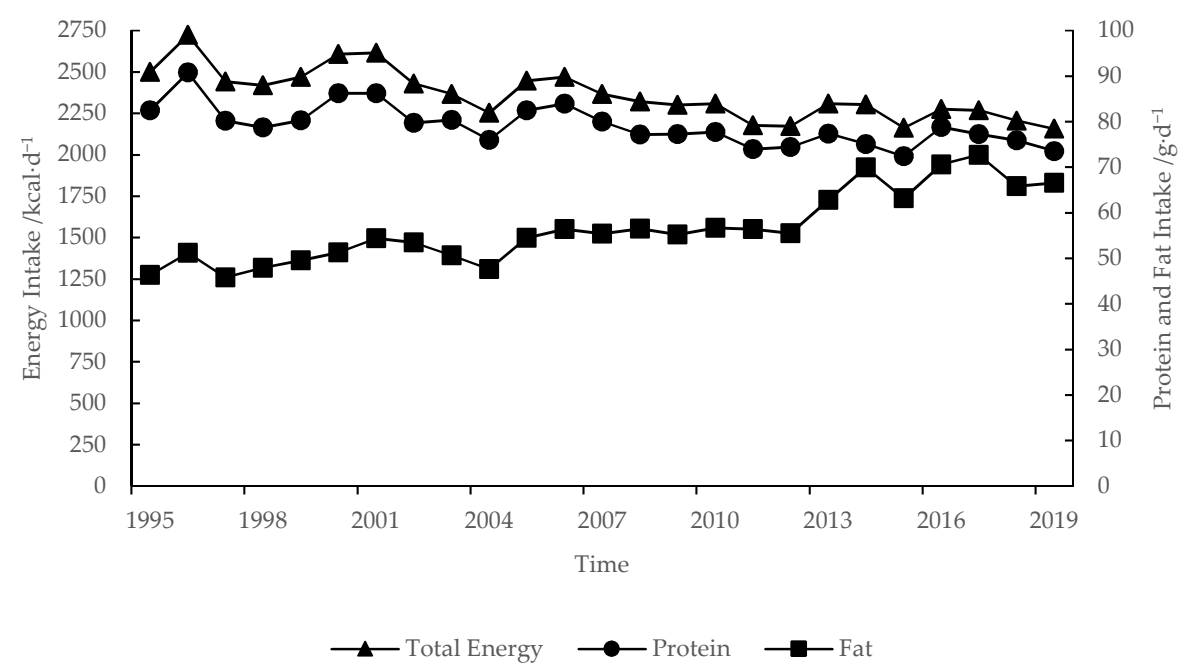

Figure 2. Per capital-nutrient intake in the QTP from 1995 to 2019.

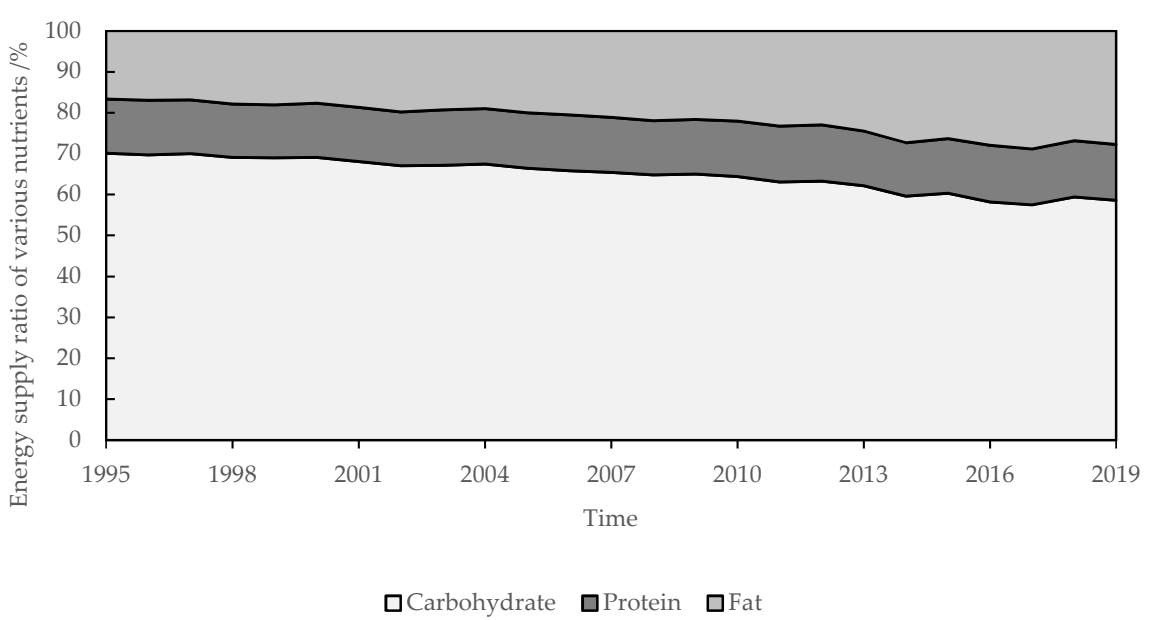

Figure 3. Per capita energy supply ratio of various nutrients in the QTP from 1995 to 2019.

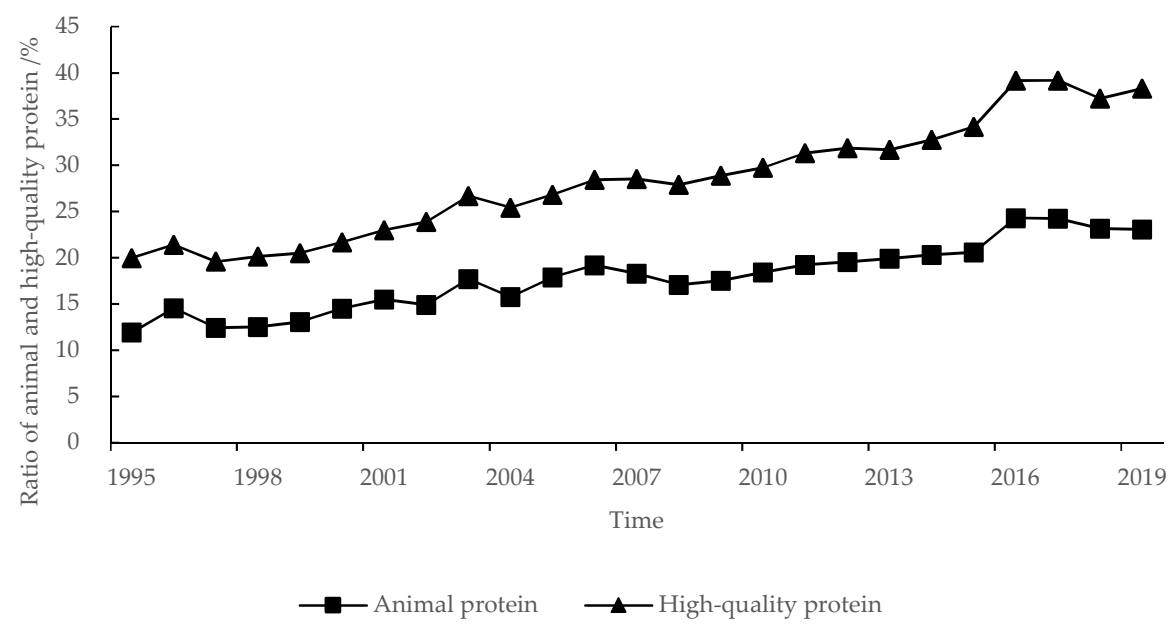

Figure 4. Ratio of animal and the high-quality protein in the QTP from 1995 to 2019.

In 2010, per capita nutrient intake of residents in the QTP reached the well-off nutritional level. Before 1995, the average daily intake of energy and protein had exceeded $2100 \mathrm{kcal} \cdot \mathrm{d}^{-1}$ and $70 \mathrm{~g} \cdot \mathrm{d}^{-1}$. In 2003 , the average daily intake of animal protein had 
exceeded $20 \%$. In 2010, the ratio of high-quality protein and energy from fat had exceeded $30 \%$ and $20 \%$.

\subsection{Per Capita Grain Consumption and Its Change}

The per capita grain consumption in the QTP decreased by $24.16 \mathrm{~kg}$ before 2007, and then remained stable (Figure 5), the anomalous percentage of each year was less than $5 \%$ (except in 2019). Among them, direct grain consumption decreased by $73.84 \mathrm{~kg}$ from 1995 to 2019 (Figures 1 and 5), which was the main reason for the reduction of grain consumption. However, it was still the main part of grain consumption, accounting for $63.47 \%$ in 2019 . The indirect grain consumption was $84.69 \mathrm{~kg}$ in 2019 , increased by $20.67 \mathrm{~kg}$ from 1995 to 2019. Among all types of indirect grain consumption, grain for fodder, industry consumption, seed consumption, and wastage consumption were 60.90, 11.75, 3.26 , and $8.78 \mathrm{~kg}$ in 2019 , respectively. The grain for fodder increased by $19.91 \mathrm{~kg}$. The proportion of grain for fodder increased from $14.39 \%$ to $26.26 \%$. The industry consumption increased by $4.29 \mathrm{~kg}$, and the seed consumption and wastage consumption decreased by 3.25 and $1.38 \mathrm{~kg}$, respectively. The proportion of their sum increased from $8.08 \%$ to $10.26 \%$. The industry consumption, seed consumption and wastage consumption were always less than the direct grain consumption and grain for fodder.

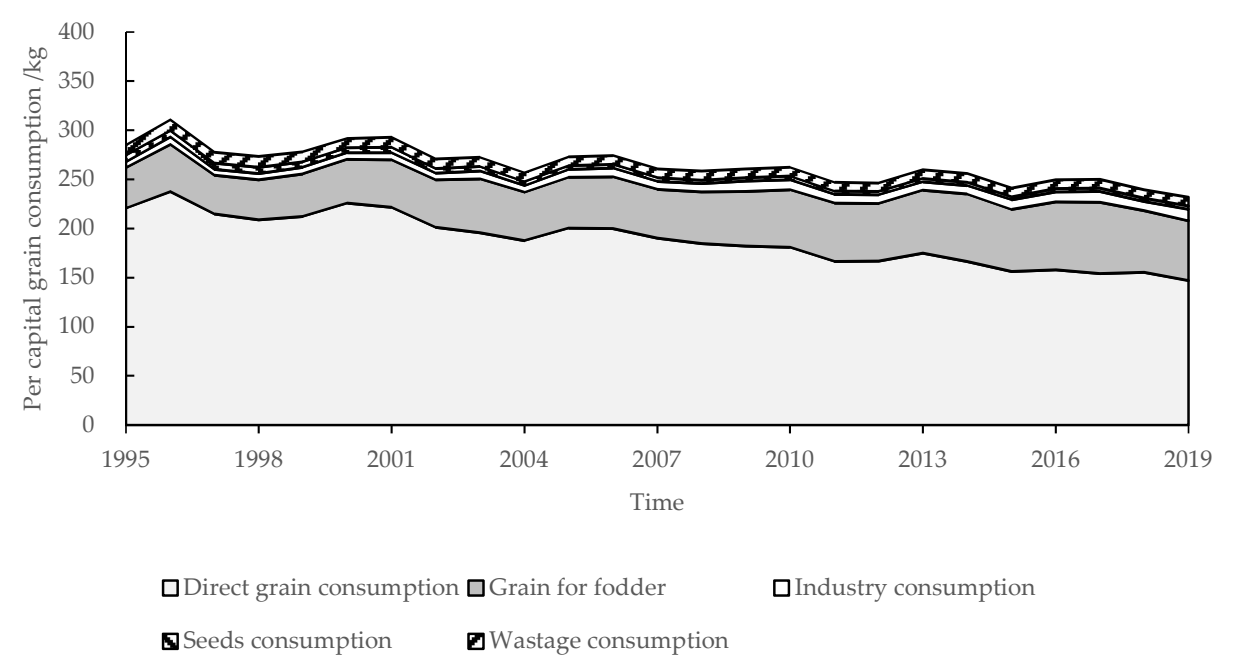

Figure 5. The structure of per capita grain consumption in the QTP from 1995 to 2019.

In this study, the maximum per capita grain consumption after 2010 was taken as the per capita grain consumption of the well-off nutritional level in the QTP, i.e., $262 \mathrm{~kg} \cdot \mathrm{a}^{-1}$.

\subsection{Comparison of Per Capita Grain Consumption between the QTP and Nationwide}

The difference in dietary structure was the main reason for the large difference in grain consumption between the QTP and the nationwide well-off nutritional level (Figure 6). The main differences were direct grain consumption and animal food (grain for fodder). The differences between direct grain consumption and grain for fodder were 39.65 and $157.25 \mathrm{~kg}$ (Figure 7). This is because the residents in the QTP consumed more non-grainconsuming animal products, such as beef, mutton, and milk, and less grain-consuming animal products, such as pork, poultry, eggs, and aquatic products than the residents in other regions. The difference of other types of grain consumption was relatively small. 


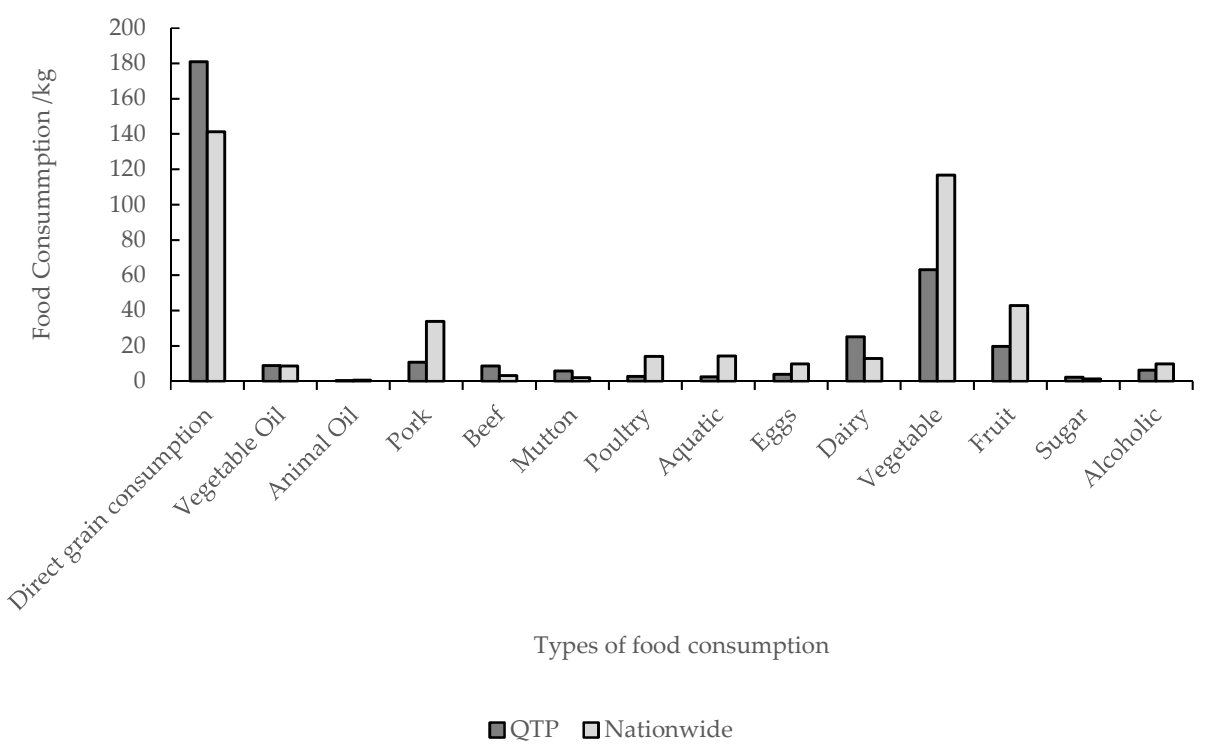

Figure 6. Per capita food consumption in the QTP and nationwide.

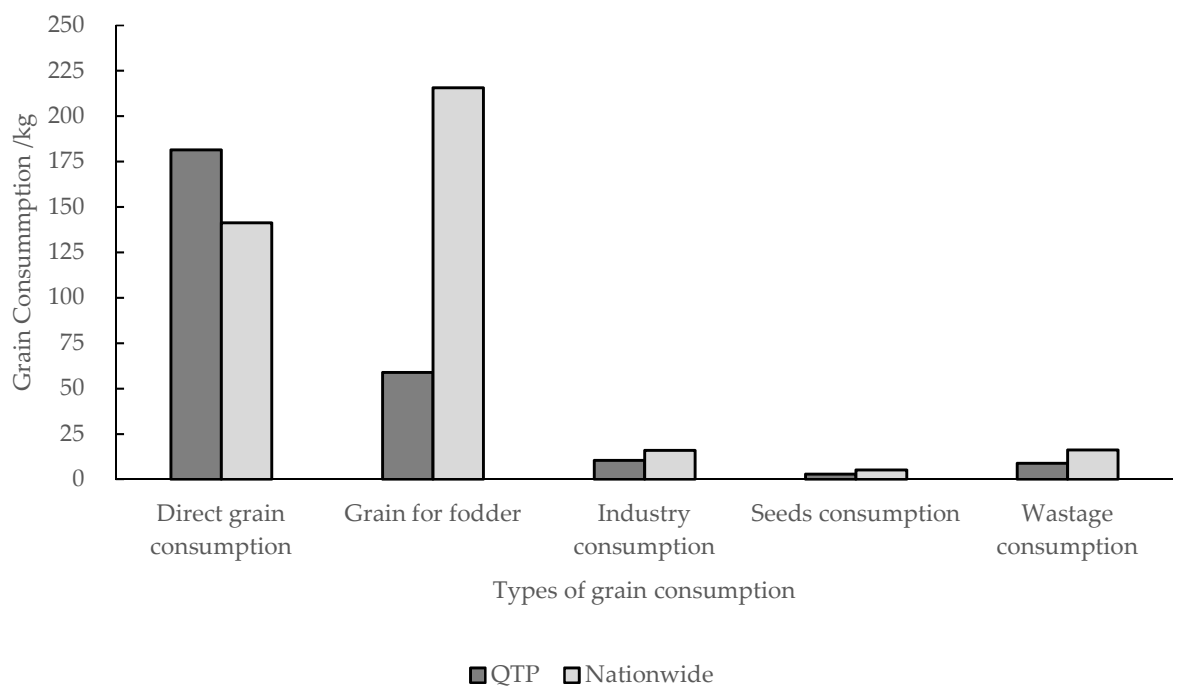

Figure 7. Per capita grain consumption of the well-off nutritional level in the QTP and nationwide.

\section{Discussion and Conclusions}

Based on the per capita food consumption of residents in the QTP from 1995 to 2019, we studied the per capita grain consumption and its change trend from the perspective of nutritional demand. Our research showed the following:

(1) Food and dietary structure of residents corresponded to physical geographic and climatic environment. The QTP is one of the traditional pastoral areas in China, food and dietary structure of residents have obvious regional characteristics, and they are still retained in modern society. The consumption of beef and mutton was high and exceeded the recommended value in the reasonable dietary pagoda of Chinese residents. The consumption of edible oil was too high, so we need to be vigilant against the occurrence of various cardiovascular and cerebrovascular diseases. The consumption of milk was also higher than that in non-pastoral regions, but it had not met the recommended standards, and a similar situation had occurred in the Hulunbuir pastoral area [42]. Among all types of food, only cereals and tubers met the recommended value standard. Cereals and tubers were the main foods, accounting for $44.26 \%$ of the total food consumption, which was different from the previous impression of the food consumption structure of "non-staple food (meat, milk and vegetables) dominated" of pastoral residents [42,43]. Other types of 
food did not meet the recommended standards (Table 1). Meanwhile, for vegetables and fruits, the QTP had never been able to feed itself, over 75\% vegetables and fruits had to be transported from other provinces, so the grain security can be regarded as food security in the QTP.

Table 1. Comparison with the dietary pagoda of Chinese residents.

\begin{tabular}{cccc}
\hline Types of Food & $\begin{array}{c}\text { The Reasonable } \\
\text { Dietary Pagoda of } \\
\text { Chinese Residents }\end{array}$ & $\begin{array}{c}\text { Food Consumption } \\
\text { of QTP Residents }\end{array}$ & Result \\
\hline Oil & $25-30$ & 38.16 & Excessive \\
Milk & 300 & 63.40 & Insufficient \\
Pulse and nut & $25-35$ & 15.89 & Insufficient \\
Meat and Poultry & $40-75$ & 97.86 & Excessive \\
Aquatic products & $40-75$ & 8.90 & Insufficient \\
Eggs & $40-50$ & 13.01 & Insufficient \\
Vegetable & $300-500$ & 190.42 & Insufficient \\
Fruit & $200-350$ & 69.77 & Insufficient \\
Cereals and tubers & $250-400$ & 387.34 & Meet \\
\hline
\end{tabular}

(2) In 2010, residents in the QTP met all indicators of the well-off nutritional level. Due to the change of dietary structure of residents, energy intake decreased from $2451.61 \mathrm{kcal} \cdot \mathrm{d}^{-1}$ in 1995 to $2309.52 \mathrm{kcal} \cdot \mathrm{d}^{-1}$ in 2010 , and then to $2156.21 \mathrm{kcal} \cdot \mathrm{d}^{-1}$ in 2019 , which was consistent with the changing trend of national per capita energy intake [44-47]. The reference value of per capita energy intake in the Chinese Dietary Reference Intakes also decreased from $2254.89 \mathrm{kcal} \cdot \mathrm{d}^{-1}$ in 2000 to $2038.58 \mathrm{kcal} \cdot \mathrm{d}^{-1}$ in 2013 [41]. Beef and mutton have lower energy, lower fat, and higher protein than pork [40]. In addition, residents consumed a lot of beef, mutton, and milk. Therefore, the protein intake of residents had exceeded $70 \mathrm{~g} \cdot \mathrm{d}^{-1}$ before 1995 . With the reduction of direct grain consumption and the increase of animal products consumption, the proportion of plant protein decreased, meanwhile, the proportion of animal protein and the high-quality protein was increased year by year.

(3) The conflict between food security and the ecosystem conservation can be managed without scarifying nature as the total grain consumption was stable since 2010 and yield per unit area and total grain yield were both increasing in the QTP. The per capita grain consumption of the well-off nutritional level in the QTP was $262 \mathrm{~kg} \cdot \mathrm{a}^{-1}$, and stable since 2010, which was related to the mode of animal husbandry in this area. The QTP is an important practice area of "store grain in grassland". With the implementation of ecosystem protection and restoration programs, such as "Grain for Green", the western region fully developed animal husbandry, reformed agricultural structure, protected the ecological environment with growth of the grassland area [48]. Grazing is the main production mode of beef, mutton, and milk, and the grain was replaced by forage to feed livestock in the QTP. Therefore, the grain for fodder in the QTP, one of the indirect grain consumptions, was lower than that of nationwide, the same with other parts of indirect grain consumption. Meanwhile, the yield per unit area and total grain yield were both increasing since 2003 as agricultural condition improved [49-52]. The yield per unit area increased from 4.13 to $4.80 \mathrm{t} \cdot \mathrm{hm}^{2}$, total grain yield increased from 1.72 million ton to 2.10 million ton during 2003-2019 [36].

We transformed food into grain for they are grain-consuming products, except the vegetable and fruit, which simplified the process of food research and helps to plan land use. With the decrease of direct grain consumption and the slight increase of grain for fodder, the grain consumption will remain stable for a period time in the QTP. However, we have to know that the direct grain consumption cannot decrease all the time. It will remain stable when it is reduced to a certain amount. Additionally, the indirect grain consumption will increase with the development of the economy and food diversification in the future. Therefore, we need to survey the food consumption for a long time in the QTP. 
Grain was also related closely to ecosystem protection and restoration programs. The per capita grain yield increased from 324.76 to $410.62 \mathrm{~kg} \mathrm{a}^{-1}$ during 1980-1998 in China, since "Grain for Grain" was implemented in 2000. The per capita grain yield increased from 333.29 to $463.34 \mathrm{~kg} \mathrm{a}^{-1}$ during 2003-2013 in China, the New Round of "Grain for Grain" was implemented since 2014 [53].

We hope this study can provide some implications for coordinating food production and implementation of ecosystem protection and restoration programs for other regions, particularly in pastoral and semipastoral areas. These areas distribute in Inner Mongolia, Ningxia, Xinjiang, Gansu, Qinghai, Tibet, Sichuan, and other provinces, and cover 264 counties, 4.05 million $\mathrm{km}^{2}$, where live 46.53 million people, most of them are Tibetan, Mongolian, Uygur, Hui, and Kazak [54], and their dietary structure is similar to that of the QTP. Pastoral areas and semipastoral areas are also important implementation areas of ecosystem protection and restoration programs, such as Grain for Green, the Three-North Shelterbelt System, and the "Two Screens and Three Belts" ecological security strategy $[53,55,56]$. The insight analysis of the grain consumption in these areas can effectively plan the land resource utilization mode, which will be of great significance to the specific implementation of ecosystem protection and restoration program.

\section{Conclusions}

Food and dietary structure of residents were corresponding to physical geographic and climatic environment. In the QTP, food consumption per capital was guaranteed at the well-off level from the perspective of nutritional demand since 2010. The conflict between food security and the ecosystem conservation can be managed without scarifying nature as the total grain consumption was stable since 2010, and the yield per unit area and total grain yield were both increasing since 2003 for agricultural condition improved in the QTP.

Supplementary Materials: The following are available online at https:/ / www.mdpi.com/article/10 .3390/nu13113742/s1, Figure S1: Technology Roadmap, Table S1: Food Composition Tables.

Author Contributions: Conceptualization, L.W. and Z.O.; methodology, L.W.; software, L.W.; resources, L.W.; data curation, L.W.; writing—original draft preparation, L.W. and Y.X.; writing一review and editing, Z.O. and L.W.; supervision, Y.X.; funding acquisition, Z.O. All authors have read and agreed to the published version of the manuscript.

Funding: This research was funded by Second Tibetan Plateau Scientific Expedition and Research (2019QZKK0308).

Conflicts of Interest: The authors declare that they have no competing interests.

\section{References}

1. Shi, D.; Feng, Z. Food Consumption in a Well-off Society of China Referring to the Experiences of Some other Countries. Resour. Sci. 2004, 26, 135-142. Available online: http://www.resci.cn/CN/abstract/abstract33066.shtml (accessed on 11 October 2021).

2. Sun, Q.; Li, X.; Yang, Z.; Zhang, X. Food and nutrition security: A literature review and prospects for research. J. Nat. Resour. 2019, 34, 1782-1796. [CrossRef]

3. Christina, L. Climate Change Losing Arable Land, China Faces Stark Choice: Adapt or Go Hungry. Science 2013, $339,644-645$. [CrossRef]

4. Călinoiu, L.F.; Vodnar, D.C. Whole Grains and Phenolic Acids: A Review on Bioactivity, Functionality, Health Benefits and Bioavailability. Nutrients 2018, 10, 1615. [CrossRef] [PubMed]

5. McRae, M.P. Health Benefits of Dietary Whole Grains: An Umbrella Review of Meta-analyses. J. Chiropr. Med. 2017, 16, 10-18. [CrossRef]

6. Dong, G. Study on Regional Equilibrium of Grain Supply and Demand and Its Change Trend in China; Zhejiang University: Hangzhou, China, 2007; pp. 70-75.

7. Liu, J.; Savenije, H.H.G. Food consumption patterns and their effect on water requirement in China. Hydrol. Earth Syst. Sci. 2008, 5, 887-898. [CrossRef]

8. Tang, H.; Li, Z. Study on Per Capita Grain Demand Based on Chinese Reasonable Dietary Pattern. Sci. Agric. Sin. 2012, 45, 2315-2327. [CrossRef]

9. Xie, G.; Cheng, S.; Xiao, Y.; Lu, C.; Liu, X.; Xu, J. The Balance between Grain Supply and Demand and the Reconstruction of China's Food Security Strategy in the New Period. J. Nat. Resour. 2017, 32, 895-903. [CrossRef] 
10. Lu, L. China's Medium and Long Term Food Development Strategy; China Agriculture Press: Beijing, China, 1993 ; p. 447.

11. People's Publishing House. Outline of Food and Nutrition Development in China (2014-2020); People's Publishing House: Beijing, China, 2014.

12. Ministry of Agriculture and Rural Affairs. 2021 Outline of Food and Nutrition Development in China (2021-2035) Is under Planning. Available online: http://ifnd.caas.cn/xwzx/yw/283670.htm (accessed on 11 October 2021).

13. Yue, T.; Wang, Q.; Lu, Y.; Xin, X.; Zhang, H.; Wu, S. Change trends of food provisions in China. Glob. Planet. Chang. 2010, 72, 118-130. [CrossRef]

14. Ji, X.; Xu, Y.; Zuo, X.; Fang, W.; Lu, Y. Estimating the climatic capacity of food security in Henan Province, China under the future climate change scenarios. Chin. J. Appl. Ecol. 2020, 31, 853-862. [CrossRef]

15. Yin, P.; Fang, X. Assessment on Vulnerable Regions of Food Security in China. Acta Geogr. Sin. 2008, 63, 1064-1072. [CrossRef]

16. Zhou, J.; Shi, P.; Wang, J.; Qiao, R. Study on the Population Supporting Capacity of Gansu Based on the Cultivated Land Resources. J. Arid. Land Resour. Environ. 2007, 21, 22-28. Available online: http://www.cqvip.com/QK/96735X/20076/1000049829.html (accessed on 11 October 2021).

17. Liu, J.; Li, X.; Zhong, X. Consumption Structure of Food and the Countermeasure of Grain in Tibet. J. Mt. Sci. 2004, 22, 286-291. Available online: http:/ / shandixb.paperonce.org/oa/DArticle.aspx?type=view\&id=200450 (accessed on 11 October 2021).

18. Duan, J.; Xu, Y.; Sun, X. Spatial patterns and their changes of grain production, grain consumption and grain security in the Tibetan Plateau. J. Nat. Resour. 2019, 34, 673-688. [CrossRef]

19. Gao, L.; Xu, Z.; Cheng, S.; Xu, S.; Zhang, X.; Yu, C.; Sun, W.; Wu, J.; Qu, Y.; Ma, J. Food consumption structure and dietary nutrition of residents in rural Tibet. Resour. Sci. 2017, 39, 168-174. [CrossRef]

20. Leng, R.; Yuan, Q.; Wang, Y.; Kuang, Q.; Ren, P. Carbon Balance of Grasslands on the Qinghai-Tibet Plateau under Future Climate Change: A Review. Sustainability 2020, 12, 533. [CrossRef]

21. Hao, Q.; Feng, Z.; Yang, Y.; Zhu, H. Evaluation on land carrying capacity of Tibet based on dietary nutrients: Present and prospects. J. Nat. Resour. 2019, 34, 911-920. [CrossRef]

22. Liu, Y. Land System in the Middle Reaches of the Yarlung Zangbo River in Tibet; Science Press: Beijing, China, $1992 ;$ pp. 50-55.

23. Zeng, J. Prospect on the population carrying capacity of resource in Tibet from 1985 to 2005. Southwest China J. Agric. Sci. 2007, 20, 843-849. [CrossRef]

24. Yao, T.; Chen, F.; Cui, P.; Ma, Y.; Xu, B.; Zhu, L.; Zhang, F.; Wang, W.; AI, L.; Yang, X. From Tibetan Plateau to Third Pole and Pan-Third Pole. Bull. Chin. Acad. Sci. 2017, 32, 924-931. [CrossRef]

25. Zhang, Y.; Li, B.; Liu, L.; Zheng, D. Redetermine the region and boundaries of tibetan plateau. Geographical Research. 2021, 40, 1543-1553. [CrossRef]

26. Qinghai Provincial Bureau of Statistics. Qinghai Statistical Yearbook; China Statistics Press: Beijing, China, 2020.

27. Tibet Bureau of Statistics. Tibet Statistical Yearbook; China Statistics Press: Beijing, China, 2020.

28. Xu, J.; Chen, X.; Li, Y.; Wang, L.; Ma, J. Analysis on eating behavior of Chinese adults in 2010. Chin. J. Prev. Control Chronic Dis. 2015, 23, 684-686. [CrossRef]

29. Zhu, Y. Study on Eating out Consumption of Chinese Rural and Urban Residents; Nanjing University of Finance and Economics: Nanjing, China, 2018; pp. 17-22.

30. National Bureau of Statistics. China Yearbook of Household Survey; China Statistics Press: Beijing, China, 2009.

31. Luo, J. A Supply and Demand Analysis of Chinese Resisdents' Dietary Protein; Chinese Academy of Agricultural Sciences: Beijing, China, 2018; pp. 16-17.

32. Han, X.; Chen, Y.; Qian, X. What is the demand for grain for fodder in China. J. Agrotech. Econ. 2014, 8, 60-68. [CrossRef]

33. Hu, Y.; Zhou, Y.; Han, Y.-J.; Xu, R. Resources and Economic Effects Analysis of Reducing Food Waste. China Popul. Resour. Environ. 2013, 23, 150-155. [CrossRef]

34. Xin, X.; Xiu, D.W.; Wang, J. China's Grain Security in the New Era: Significance, Challenges and Countermeasures. Chin. J. Agric. Resour. Reg. Plan. 2021, 42, 76-84. [CrossRef]

35. Shen, Y. Baijiu Production Technology; China Light Industry Press: Beijing, China, 1998; pp. $20-25$.

36. National Bureau of Statistics. China Statistical Yearbook; China Statistics Press: Beijing, China, 2020. Available online: http: / / www.stats.gov.cn/tjsj/ndsj/ (accessed on 11 October 2021).

37. National Bureau of Statistics. Costs and Benefits of National Agricultural Products; China Statistics Press: Beijing, China, 2014.

38. Luo, J. Study on Grain Consumption Based on The Goal of Nutrition; Chinese Academy of Agricultural Sciences: Beijing, China, 2008; pp. 37-47.

39. Yang, Y. China Food Composition Tables Standard, 1st ed.; Peking University Medical Press: Beijing, China, 2018 ; pp. 27-123.

40. Yang, Y. China Food Composition Tables Standard, 2nd ed.; Peking University Medical Press: Beijing, China, $2019 ;$; pp. 52-175.

41. Chinese Nutrition Society. Chinese Dietary Reference Intakes; Science Press: Beijing, China, 2014; pp. 625-654.

42. Wang, L.E.; Ni, X.; Xu, S.; Li, Y.; Su, H.; Shi, L.; Cheng, S. Structure and Characteristics of Food Consumption of Herdsman Households in Northern China. Chin. J. Agric. Resour. Reg. Plan. 2020, 41, 1-13. [CrossRef]

43. Zhao, Y.; Zhang, Q.; Li, F.Y. Patterns and drivers of household carbon footprint of the herdsmen in the typical steppe region of inner Mongolia, China: A case study in Xilinhot City. J. Clean. Prod. 2019, 232, 408-416. [CrossRef]

44. Yu, D.; He, Y.; Guo, Q.; Fang, H.; Xu, X.; Fang, Y.; Li, J.; Zhao, L. Trends of energy and nutrients intake among Chinese population in 2002-2012. J. Hyg. Res. 2016, 45, 527-533. [CrossRef] 
45. Zhang, B.; Wang, H.; Du, W.; Zhang, J.; Su, C.; Zhai, F. The Trends of Nutrients Intake of Chinese Residents in Nine Provinces from 1989 to 2009. Acta Nutr. Sin. 2011, 33, 237-242. [CrossRef]

46. Zhu, Z.; Yang, X.; Fang, Y.; Zhang, J.; Yang, Z.; Wang, Z.; Liu, A.; He, L.; Sun, J.; Lian, Y.; et al. Trends and Disparities of Energy Intake and Macronutrient Composition in China: A Series of National Surveys, 1982-2012. Nutrients 2020, 12, 2168. [CrossRef]

47. Liu, A.; Han, A.; Chai, L. Assessing the Nutrient Adequacy in China's Food Supply from 1965 to 2018. Nutrients 2021, 13, 2734. [CrossRef]

48. Ren, J. Establishment of an agro-grassland systems for grain storage-A thought on restructure of agricultural framework in Western China. Acta Prataculturae Sin. 2002, 11, 1-3. [CrossRef]

49. Sun, T.; Feng, Z.; Yang, Y. Study on Spatiotemporal Patterns and Contribution Factors of China's Grain Output Increase at the County Level during 2003-2013. J. Nat. Resour. 2017, 32, 177-185. [CrossRef]

50. Ding, R.; Shi, W. Quantitative evaluation of the effects of climate change on cereal yields of Tibet during 1993-2017. Acta Geogr. Sin. 2021, 76, 1-13. [CrossRef]

51. Ren, X.; Nevo, E.; Sun, D.; Sun, G. Tibet as a Potential Domestication Center of Cultivated Barley of China. PLoS ONE 2013, 8, e62700. [CrossRef] [PubMed]

52. Deng, N.; Zheng, B.; Li, T.; Liu, R.H. Assessment of the Phenolic Profiles, Hypoglycemic Activity, and Molecular Mechanism of Different Highland Barley (Hordeum vulgare L.) Varieties. Int. J. Mol. Sci. 2020, 21, 1175. [CrossRef] [PubMed]

53. National Forestry and Grassland Administration. Twenty years of "Grain for Green" in China: 1-29. 2020. Available online: http:/ / www.forestry.gov.cn/html/main/main_195/20200630085813736477881/file/20200630090428999877621.pdf (accessed on 11 October 2021).

54. National Bureau of Statistics. China Statistical Yearbook (County-Level); China Statistics Press: Beijing, China, 2019.

55. Ouyang, Z.; Zheng, H. Ecological Security Strategy; Science Press: Beijing, China, 2014; pp. 77-125.

56. Wang, X.; Li, Y.; Chu, B.; Liu, S.; Yang, D.; Luan, J. Spatiotemporal Dynamics and Driving Forces of Ecosystem Changes: A Case Study of the National Barrier Zone, China. Sustainability 2020, 12, 6680. [CrossRef] 